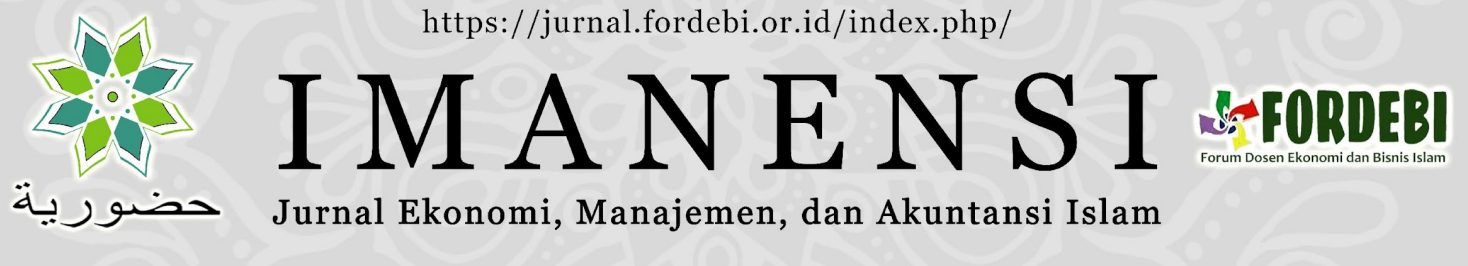

\title{
PERAN EMOSI PELANGGAN SEBAGAI PENENTU LOYALITAS PELANGGAN RESTORAN
}

\author{
Amabela $^{\mathrm{a}, 1}$, Erna Andajani ${ }^{\mathrm{b}, 2^{*}}$, Juliani Dyah Trisnawati ${ }^{\mathrm{c}, 3}$ \\ a,b,c Universitas Surabaya, Jl. Raya Kalirungkut, Surabaya, Jawa Timur, 60293, Indonesia \\ 1amabela1998@gmail.com; 2ernajani@staff.ubaya.ac.id*; 3 juliani@staff.ubaya.ac.id
}

*Corresponding author

\author{
INFO ARTIKEL \\ IMANENSI \\ Volume 7 \\ Nomor 1 \\ Halaman 41-52 \\ Malang, Maret 2022 \\ ISSN: 2339-1847 \\ e-ISSN: 2683-9968

\section{Kronologi Artikel:} \\ Tanggal Masuk: \\ 21 April 2021 \\ Tanggal Revisi: \\ 22 Februari 2022 \\ Tanggal Diterima: \\ 5 Maret 2022 \\ Kata Kunci: \\ Emosi; \\ Kualitas Layanan; \\ Kualitas Makanan; \\ Loyalitas; \\ Pelanggan Lain; \\ Suasana.

\section{Keywords:} \\ Atmospherics; \\ Emotions; \\ Food Quality; \\ Loyalty; \\ Other Customers; \\ Service Quality.
}

\begin{abstract}
Abstrak: Peran Emosi Pelanggan Sebagai Penentu Loyalitas
Pelanggan Restoran. Penelitian ini bertujuan menganalisis pengaruh kualitas makanan, kualitas layanan, suasana, pelanggan lain, dan emosi positif serta negatif terhadap loyalitas pelanggan. Metode penelitian menggunakan analisis model pengukuran dan sruktural. Adapun sampel yang digunakan adalah konsumen restoran Domicile Kitchen \& Lounge Surabaya. Penelitian ini menemukan emosi pelanggan yang sifatnya postif dan negatif menjadi penentu loyalitas pelanggan. Emosi positif dan negatif dalam penelitian ini dipengaruhi faktor kualitas makanan dan pelayanan serta pelanggan lain, sedangkan suasana tidak memiliki pengaruh terhadap emosi positif dan negatif. Implikasi penelitian bagi pemilik restauran agar tetap menjaga kualitas layanan dan makanan dengan memberikan feedback dan melakukan evaluasi.
\end{abstract}

\begin{abstract}
The Role of Customer Emotions as Determinants of Restaurant Customer Loyalty. This study aims to analyze the effect of food quality, service quality, atmosphere, other customers, and positive and negative emotions on customer loyalty. The research method uses measurement and structural model analysis. The sample used is the Domicile Kitchen \& Lounge Surabaya restaurant consumers. This study found that positive and negative customer emotions determine customer loyalty. Positive and negative emotions in this study were influenced by the quality of food and service as well as other customers, while the atmosphere had no influence on positive and negative emotions. The research implication is for restaurant owners to maintain the quality of service and food by providing feedback and conducting evaluations.
\end{abstract}

\section{PENDAHULUAN}

Pertumbuhan perekonomian global pada saat ini telah memasuki situasi dimana persaingan antar pelaku bisnis menjadi menu utama sehari-hari. Di era persaingan global saat ini, perusahaan yang ingin tetap eksis dituntut untuk harus selalu memperbarui inovasi dan kreativitas dalam memberikan layanan yang terbaik 
bagi pelanggannya. Hal ini dikarenakan pelanggan memiliki peranan penting bagi eksistensi dan keberlangsungan suatu perusahaan (Asshidieqi, 2012).

Hal yang telah diuraikan diatas juga berlaku bagi bisnis restoran. Restoran kini tidak hanya menjadi tempat untuk makan, tetapi menjadi sebuah tren di masyarakat. Banyak saat ini masyarakat yang sudah mulai menyadari pentingnya mengkonsumsi makanan bergizi untuk menjaga kesehatan. (Ayodya, 2007). Makanan dengan kualitas premium biasanya dijual di restoran-restoran mewah. Selain itu, masyarakat juga memperhatikan persepsi dari orang lain tentang kebanggaan tersendiri apabila bisa makan di restoran mewah (https://www.selasar.com). Ketua Asosiasi Pengusaha Kafe dan Restoran Indonesia (Apkrindo) Jatim, Tjahjono Haryono mengatakan bahwa jumlah kafe dan restoran terus bertambah di Jawa Timur khususnya di daerah Surabaya. Surabaya mengalami pertumbuhan sebesar $20 \%$ pada industri kafe dan restoran pada tahun 2018. (https://www.jpnn.com).

Gambar 1 menunjukkan bahwa pada tahun 2017, salah satu jenis restoran yang paling banyak ditemui di Surabaya selain Cafe adalah restoran dengan menu Indonesia, Chinese, dan Western. Restoran Western sendiri merupakan salah satu jenis restoran yang sedang berkembang saat ini dan identik dengan restoranrestoran mewah. Di Surabaya sendiri juga sudah terdapat banyak restoran Western. Banyaknya restoran Western di Surabaya saat ini, membuat banyak restoran Western semakin memacu diri untuk berinovatif sehingga semakin banyaknya ragam pilihan serta variasi rasa dan tekstur yang dengan kualitas yang baik. Pada Tabel 1 menunjukkan data adanya Restoran Western mewah di Surabaya, dimana salah satu restoran Western di Surabaya yaitu Domicile Kitchen \& Lounge Surabaya.

Domicile Kitchen \& Lounge merupakan salah satu restoran mewah di Surabaya yang berlokasi di jalan Sumatra 35, Surabaya. Merupakan salah satu fine dining terbaik di Surabaya. Harga makanan di restoran ini berkisar antara Rp80.000 hingga Rp1.250.000. Interior restoran ini sangat elegan dan klasik. Ada taman dan kolam di tengah-tengah restoran, sehingga menambah kesan romantis. Suasana di restoran ini sangat romantis dilengkapi dengan alunan musik lembut dan lampu restoran yang cenderung berwarna kuning sehingga menimbulkan kesan nyaman dan pelanggan tidak akan merasa bosan. Karena suasana yang nyaman dan tempat yang bagus, apalagi ditambah dekorasi yang menarik dapat menarik pelanggan untuk datang ke restoran ini. Selain itu, meskipun harga makanan terbilang mahal, cita rasa dari makanan juga berkualitas. Sehingga antara harga yang ditawarkan dengan makanan yang disajikan sangatlah sesuai. Restoran Domicile Kitchen \& Lounge ini menarik untuk dijadikan objek penelitian terkait dengan variable food quality, service quality, atmospherics, positive emotions dan negative emotions.

Tabel 1. Restoran Western Mewah di Surabaya

\begin{tabular}{ll}
\hline No. & Luxury Restaurant \\
\hline 1 & Brassery \\
2 & De Soematra 1910 \\
3 & Domicile Kitchen \& Lounge \\
4 & Platinum Grill \\
5 & Angus House \\
\hline (Sumber: https://www.tripadvisor.co.id)
\end{tabular}

(Sumber: https://www.tripadvisor.co.id) 


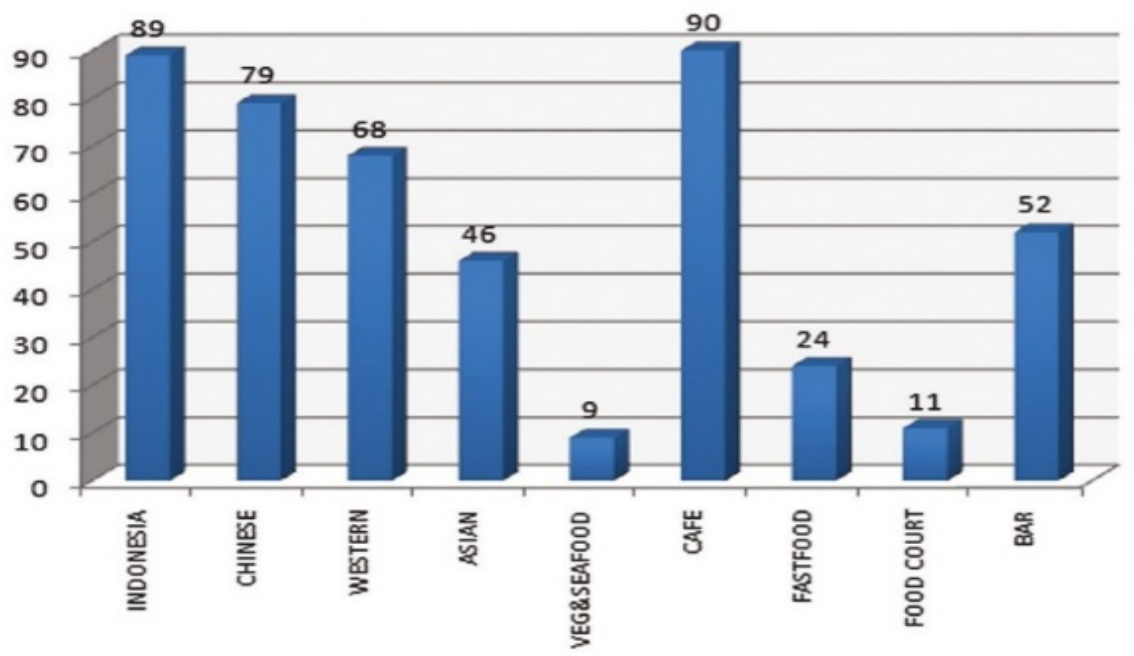

(Sumber: pariwisatasurabaya.com)

\section{Gambar 1. Jumlah Restoran di Surabaya Berdasarkan Jenis Makanan Tahun 2017}

Merujuk pada penelitian Chen et al. (2015) dan Peng et al. (2016) yang menggunakan obyek resto ditemukan ada perbedaan hasil penelitian. Pada penelitian Chen et al. (2015) diketahui bahwa Food Quality tidak memiliki pengaruh terhadap Positive Emotions dan Atmospherics memiliki pengaruh terhadap Positive Emotions, tetapi tidak memiliki pengaruh terhadap Negative Emotions. Namun pada penelitian Peng et al. (2016) menemukan bahwa Food Quality memiliki pengaruh terhadap Positive Emotions dan Atmospherics tidak memiliki pengaruh terhadap Positive Emotions, tetapi memiliki pengaruh terhadap Negative Emotions. Perbedaan ini hasil penelitian menarik untuk diteliti lagi dengan menggunakan obyek penelitian di wilayah geografi berbeda. Hal ini dilakukan untuk menguji kemapanan teori. Pada penelitian ini bertujuan untuk menguji pengaruh variable Positive Emotions dan Atmospherics terhadap Positive Emotions dan Negative Emotions.

\section{METODE}

Berdasarkan penelitian, penelitian ini termasuk dalam basic research dikarenakan tujuan dari penelitian ini adalah untuk mengetahui, menjelaskan dan memprediksikan fenomena alam dan lingkungan sosial yang terjadi. Sedangkan bila berdasarkan tujuan dari penelitian, penelitian ini termasuk pada jenis penelitian kausal, dimana penelitian kausal memiliki tujuan untuk mengidentifikasi hubungan sebab-akibat dari hubungan antar variabel (Zikmund dkk, 2009). Alat analisis yang digunakan untuk mengolah data adalah AMOS SEM. Penelitian ini bertujuan untuk menguji hipotesis yang ada, yaitu ada atau tidaknya pengaruh positif dan pengaruh negatif dari variabel food quality, service quality, atmospherics, other customers terhadap positive dan negative emotions pada restoran Domicile Kitchen \& Lounge Surabaya.

Jenis data yang digunakan dalam penelitian ini adalah data primer yaitu data yang diperoleh langsung dari responden melalui pembagian kuesioner untuk memperoleh tanggapan ataupun pendapat responden berdasarkan pertanyaanpertanyaan tertulis yang berada pada kuesioner tersebut. Kuesioner dibagikan kepada responden sesuai dengan karakteristik yang telah ditetapkan peneliti sebelumnya. Aras pengukuran yang digunakan dalam penelitian ini adalah aras 
interval. Aras interval merupakan aras pengukuran yang memiliki jarak yang sama dan selisih yang jelas pada skala. Kuesioner yang dibagikan kepada responden bersifat tertutup (close ended question) yaitu jawaban responden telah dibatasi dengan menyediakan alternatif jawaban. Alternatif jawaban yang disediakan untuk aras interval disusun berdasarkan skala numeris (numerical scale) yang dilakukan dengan memberikan penilaian pada serangkaian pertanyaan yang diukur dalam tujuh skala jenjang.

Target populasi dalam penelitian ini adalah konsumen restoran Domicile Kitchen \& Lounge Surabaya yang berdomisili di Surabaya dan pernah mengunjungi restoran Domicile Kitchen \& Lounge Surabaya. Karakteristik populasi yang ditetapkan adalah pria atau wanita, bertempat tinggal di Surabaya, pernah mengunjungi restoran Domicile Kitchen \& Lounge Surabaya minimal sekali dalam tiga bulan terakhir untuk membeli makanan dan minuman, memiliki pendidikan terakhir minimal SMA/SMK/sederajat dan berusia minimal 18 tahun. Hasil penyebaran kuesioner diperoleh 150 responden dan sebanyak $70 \%$ berjenis kelamin wanita. Responden berprofesi sebagai pelajar/mahasiswa sebanyak 57\% dan mayoritas berusia 18-24 tahun sebanyak 67,3\%.

Sampel merupakan bagian dari populasi yang karakteristiknya hendak diteliti dan biasanya mewakili keseluruhan populasi. Karena populasi responden tidak diketahui maka penelitian ini menggunakan non probability sampling. Jumlah populasi yang dipilih sebagai sampel adalah berdasarkan keputusan peneliti dan dibatasi oleh karakteristik tertentu yang telah ditetapkan. Teknik pengambilan sampel adalah dengan menggunakan teknik non probability sampling. Jumlah populasi yang dipilih sebagai sampel adalah berdasarkan keputusan peneliti dan dibatasi oleh karakteristik tertentu yang telah ditetapkan. Jenis non probability sampling yang digunakan adalah purposive sampling. Purposive sampling yaitu teknik mendapatkan sampel dari orang-orang yang memenuhi beberapa kriteria yang ditentukan (Cozby dan Bates, 2020).

\section{HASIL DAN PEMBAHASAN}

Pada bagian hasil dan pembahasan, akan dibagi menjadi 2 bagian, yang pertama yaitu model pengukuran dan bagian kedua adalah model struktural. Setelah penyajian measurement model dilanjutkan menghitung nilai estimasi dan signifikansi hubungan antara indikator dan konstruk. Pada bagain akhir disajikan structural model. Pada model pengukuran dan model struktural ditampilkan hasil Goodness of Fit Index, CMIN/DF, RMSEA, CFI, dan TLI.

\subsection{Model Pengukuran}

Bagian ini akan dibahas hasil dari average variance extracted (AVE) dan hasil dari construct reliability. Fungsi dari average variance extracted (AVE) adalah untuk menunjukkan validitas. Selain menggunakan nilai dari standardized loading dan hasil average variance extracted (AVE) yang tinggi menunjukkan bahwa indikatorindikator yang digunakan pada penelitian telah mewakili secara baik setiap konstruk laten yang telah dikembangkan (Ferdinand, 2002:63). Nilai dari average variance extracted (AVE) yang disarankan oleh Ferdinand (2002) pada model penelitian adalah nilai dari average variance extracted (AVE) memiliki nilai $\geq 0,50$. Pada tabel 2 ditampilkan nilai standardized loading, AVE, dan CR tiap indikator. Seluruh indikator memiliki nilai standardized loading $\geq 0,50$ juga memiliki AVE dan CR sesuai kriteria sehingga indikator-indikator tersebut memiliki validitas dan reliabilitas yang baik. 
Tabel 1. Hasil Uji Kecocokan Model Pengukuran

\begin{tabular}{lllll}
\hline No & Goodness of Fit Index & Kriteria Kecocokan & Hasil & Keterangan \\
\hline 1 & CMIN/DF & CMIN/DF $\leq 3,0$ & 1,042 & Good Fit \\
2 & RMSEA & RMSEA $\leq 0,08$ & 0,017 & Good Fit \\
3 & AGFI & AGFI $\geq 0,90$ & 0,809 & Marginal Fit \\
4 & GFI & GFI $\geq 0,90$ & 0,837 & Marginal Fit \\
5 & CFI & CFI $\geq 0,95$ & 0,996 & Good Fit \\
6 & TLI & TLI $\geq 0,95$ & 0,996 & Good Fit \\
\hline
\end{tabular}

Tabel 2. Hasil Perhitungan AVE dan CR

\begin{tabular}{|c|c|c|c|c|c|c|c|}
\hline $\begin{array}{l}\text { Variab } \\
\text { el }\end{array}$ & Item & $\begin{array}{l}\text { Std } \\
\text { Loading } \\
(\lambda)\end{array}$ & $\begin{array}{l}\text { Std } \\
\text { Loading } \\
\left(\lambda^{\wedge} 2\right)\end{array}$ & $\begin{array}{l}\text { Measurement } \\
\text { Error }\end{array}$ & AVE & $\mathrm{CR}$ & Keterangan \\
\hline \multirow{5}{*}{$F Q$} & FQ1 & 0,949 & 0,901 & 0,099 & \multirow{5}{*}{0,826} & \multirow{5}{*}{0,960} & \multirow{5}{*}{$\begin{array}{l}\text { Valid dan } \\
\text { Reliabel }\end{array}$} \\
\hline & FQ2 & 0,923 & 0,852 & 0,148 & & & \\
\hline & FQ3 & 0,937 & 0,878 & 0,122 & & & \\
\hline & FQ4 & 0,907 & 0,823 & 0,177 & & & \\
\hline & FQ5 & 0,823 & 0,677 & 0,323 & & & \\
\hline \multirow{5}{*}{$S Q$} & SQ1 & 0,871 & 0,759 & 0,241 & \multirow{5}{*}{0,802} & \multirow{5}{*}{0,953} & \multirow{5}{*}{$\begin{array}{l}\text { Valid dan } \\
\text { Reliabel }\end{array}$} \\
\hline & SQ2 & 0,937 & 0,878 & 0,122 & & & \\
\hline & SQ3 & 0,910 & 0,828 & 0,172 & & & \\
\hline & SQ4 & 0,889 & 0,790 & 0,210 & & & \\
\hline & SQ5 & 0,869 & 0,755 & 0,245 & & & \\
\hline \multirow{5}{*}{$A$} & A 1 & 0,929 & 0,863 & 0,137 & \multirow{5}{*}{0,883} & \multirow{5}{*}{0,974} & \multirow{5}{*}{$\begin{array}{l}\text { Valid dan } \\
\text { Reliabel }\end{array}$} \\
\hline & A2 & 0,925 & 0,856 & 0,144 & & & \\
\hline & A3 & 0,959 & 0,920 & 0,080 & & & \\
\hline & A4 & 0,957 & 0,916 & 0,084 & & & \\
\hline & A5 & 0,929 & 0,863 & 0,137 & & & \\
\hline \multirow{5}{*}{$O C$} & OC1 & 0,908 & 0,824 & 0,176 & \multirow{5}{*}{0,844} & \multirow{5}{*}{0,964} & \multirow{5}{*}{$\begin{array}{l}\text { Valid dan } \\
\text { Reliabel }\end{array}$} \\
\hline & $\mathrm{OC} 2$ & 0,931 & 0,867 & 0,133 & & & \\
\hline & OC3 & 0,956 & 0,914 & 0,086 & & & \\
\hline & OC4 & 0,940 & 0,884 & 0,116 & & & \\
\hline & OC5 & 0,855 & 0,731 & 0,269 & & & \\
\hline \multirow{5}{*}{$P E$} & PE1 & 0,929 & 0,863 & 0,137 & \multirow{5}{*}{0,864} & \multirow{5}{*}{0,969} & \multirow{5}{*}{$\begin{array}{l}\text { Valid dan } \\
\text { Reliabel }\end{array}$} \\
\hline & PE2 & 0,936 & 0,876 & 0,124 & & & \\
\hline & PE3 & 0,944 & 0,891 & 0,109 & & & \\
\hline & PE4 & 0,917 & 0,841 & 0,159 & & & \\
\hline & PE5 & 0,921 & 0,848 & 0,152 & & & \\
\hline \multirow{5}{*}{$N A$} & NA1 & 0,856 & 0,733 & 0,267 & \multirow{5}{*}{0,769} & \multirow{5}{*}{0,943} & \multirow{5}{*}{$\begin{array}{l}\text { Valid dan } \\
\text { Reliabel }\end{array}$} \\
\hline & NA2 & 0,866 & 0,750 & 0,250 & & & \\
\hline & NA3 & 0,899 & 0,808 & 0,192 & & & \\
\hline & NA4 & 0,868 & 0,753 & 0,247 & & & \\
\hline & NA5 & 0,896 & 0,803 & 0,197 & & & \\
\hline \multirow{5}{*}{$L$} & L1 & 0,946 & 0,895 & 0,105 & \multirow{5}{*}{0,859} & \multirow{5}{*}{0,968} & \\
\hline & L2 & 0,917 & 0,841 & 0,159 & & & \\
\hline & L3 & 0,935 & 0,874 & 0,126 & & & Val1d dan \\
\hline & L4 & 0,919 & 0,845 & 0,155 & & & \\
\hline & L5 & 0,917 & 0,841 & 0,159 & & & \\
\hline
\end{tabular}

Model struktural adalah salah satu metode untuk pengujian hipotesis, untuk mencari tahu apakah hipotesis terdukung/supported atau tidak terdukung/not supported. Pengujian hipotesis dilakukan dengan melihat nilai CR (critical ratio) yang dihasilkan dari perhitungan loading dari setiap hubungan antar konstruk yang terdapat dalam model penelitian untuk setiap koefisien. Suatu konstruk dapat dikatakan memiliki pengaruh yang signifikan pada konstruk lain apabila nilai critical 
ratio $(\mathrm{CR})) \geq 1,96$ (dengan tingkat signifikansi $5 \%$ ) atau nilai $p$-value $<0,05$. Dari tabel 2 mengenai data hasil uji kecocokan model struktural, diketahui semua penilaian uji kecocokan Goodness of Fit Index pada model struktural, semuanya memiliki fit, dimana pada indeks CMIN/DF, RMSEA, CFI, dan TLI semuanya tergolong good fit, sedangkan pada indeks AGFI dan GFI tergolong marginal fit dengan nilai 0,810 dan 0,836. Namun marginal fit masih dapat diterima.

\subsection{Pengujian Hipotesis}

Setelah melakukan proses analisis dari data yang dikumpulkan dan melakukan analisis model pengukuran (measurement model) dan model struktural (structural model) beserta sudah melakukan penyesuaian indeks Goodness of Fit, maka langkah berikutnya adalah menghitung nilai dari critical ratio (CR) atau nilai $P$-value guna untuk mengetahui apakah hipotesis terdukung/supported. Hipotesis terdukung apabila nilai dari critical ratio $(\mathrm{CR}) \geq 1,96$ atau nilai dari $P$-Value $<0,05$. Hal tersebut dapat dilihat di tabel 3 yang berisi data hasil uji hipotesis.

Tabel 3. Hasil Uji Kecocokan Model Struktural

\begin{tabular}{lllll}
\hline No & Goodness of Fit Index & Kriteria Kecocokan & Hasil & Keterangan \\
\hline 1 & CMIN/DF & CMIN/DF $\leq 3,0$ & 1,044 & Good Fit \\
2 & RMSEA & RMSEA $\leq 0,08$ & 0,017 & Good Fit \\
3 & AGFI & AGFI $\geq 0,90$ & 0,810 & Marginal Fit \\
4 & GFI & GFI $\geq 0,90$ & 0,836 & Marginal Fit \\
5 & CFI & CFI $\geq 0,95$ & 0,996 & Good Fit \\
6 & TLI & TLI $\geq 0,95$ & 0,996 & Good Fit \\
\hline
\end{tabular}

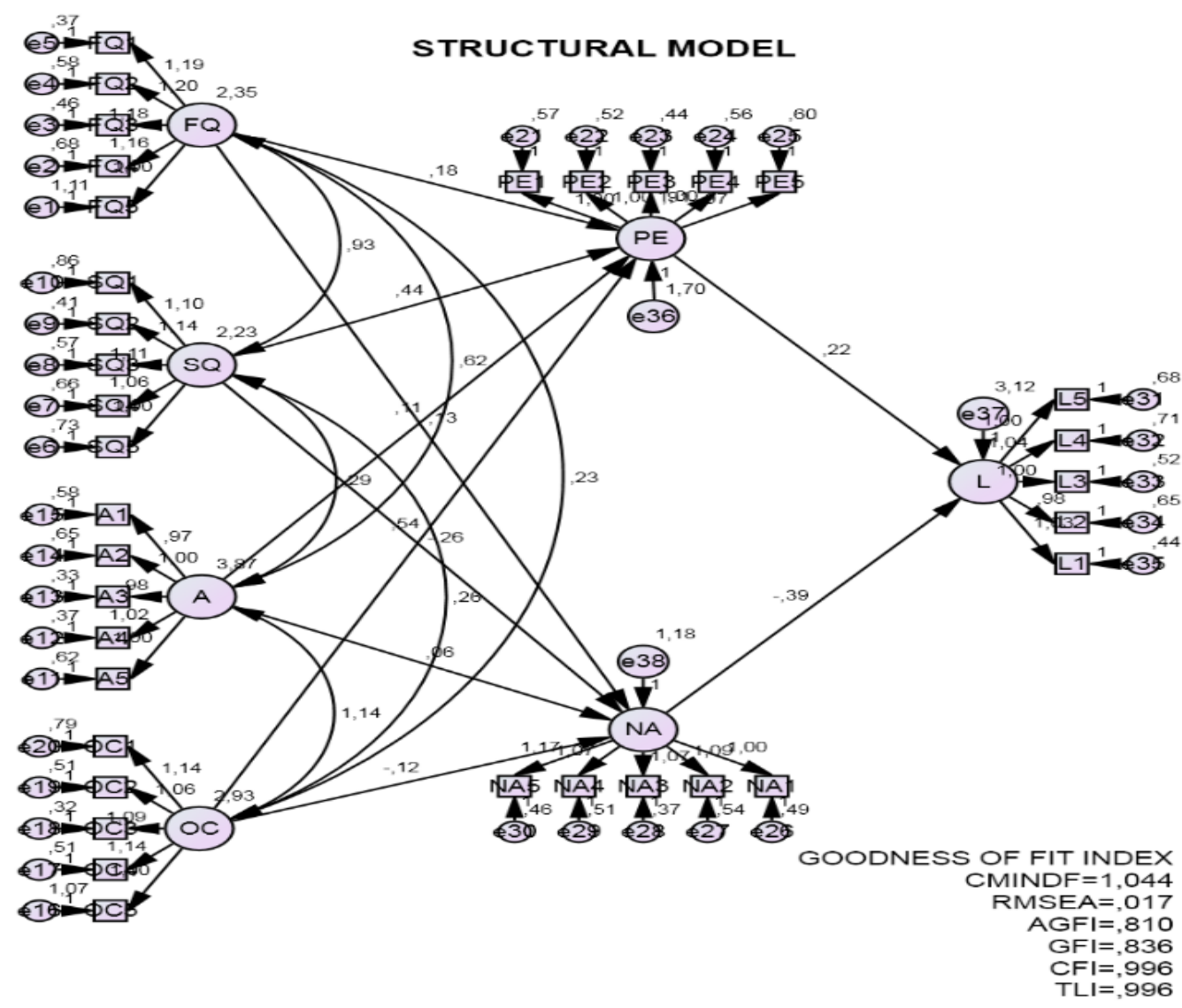

Gambar 3. Model Struktural 
Tabel 4. Hasil Uji Hipotesis

\begin{tabular}{llllll}
\hline Hipotesis & $\begin{array}{l}\text { Hub. Antar } \\
\text { variabel }\end{array}$ & $\begin{array}{l}\text { Std } \\
\text { estimate }\end{array}$ & $\begin{array}{l}\text { Critical } \\
\text { Ratio (CR) }\end{array}$ & P-value & Keterangan \\
\hline H1a (+) & FQ $\rightarrow$ PE & 0,183 & 2,177 & 0,029 & Hipotesis terdukung \\
H1b (-) & FQ $\rightarrow$ NA & 0,129 & 1,849 & 0,064 & Hipotesis tidak terdukung \\
H2a (+) & SQ $\rightarrow$ PE & 0,438 & 4,976 & $* * *$ & Hipotesis terdukung \\
H2b (-) & SQ $\rightarrow$ NA & $-0,255$ & $-3,530$ & $* * *$ & Hipotesis terdukung \\
H3a (+) & A $\rightarrow$ PE & 0,109 & 1,734 & 0,083 & Hipotesis tidak terdukung \\
H3b (-) & A $\rightarrow$ NA & 0,061 & 1,167 & 0,243 & Hipotesis tidak terdukung \\
H4a (+) & OC $\rightarrow$ PE & 0,541 & 6,992 & $* * *$ & Hipotesis terdukung \\
H4b (-) & OC $\rightarrow$ NA & $-0,124$ & $-2,089$ & 0,037 & Hipotesis terdukung \\
H5a (+) & PE $\rightarrow$ L & 0,216 & 2,637 & 0,008 & Hipotesis terdukung \\
H5b (-) & NA $\rightarrow$ L & $-0,386$ & $-2,834$ & 0,005 & Hipotesis terdukung \\
\hline
\end{tabular}

Keterangan: *** Koefisien signifikan pada $P$-value $\leq 0,001$

Dari data hasil pada tabel 3 menunjukkan bahwa terdapat 3 hipotesis terdukung secara penuh, 1 hipotesis tidak terdukung, dan 1 hipotesis terdukung sebagian. Hipotesis yang terdukung secara penuh adalah $\mathrm{H} 2, \mathrm{H} 4$, dan $\mathrm{H} 5$. Hipotesis yang terdukung sebagian adalah $\mathrm{H} 1$, dan hipotesis yang tidak terdukung adalah $\mathrm{H} 3$.

\subsection{Pengaruh Food Quality terhadap Emotions}

Hipotesis $\mathrm{H} 1 \mathrm{a}$, yaitu hubungan pengaruh variabel food quality terhadap positive emotions memiliki hasil uji yang signifikan dan pengaruh positif. Dengan demikian $\mathrm{H} 1 \mathrm{a}$ dari penelitian ini terdukung. Selain itu, hasil penelitian ini tidak sesuai dengan hasil penelitian Chen et al. (2015), namun sesuai dengan hasil penelitian yang dilakukan oleh Peng et al. (2016). Dalam bisnis restoran, kualitas makanan adalah salah satu hal terpenting yang akan dipertimbangkan oleh konsumen. Ramanathan et al. (2016) mengatakan bahwa food quality adalah faktor paling berpengaruh secara signifikan terhadap kepuasan konsumen, selain harga makanan, lingkungan dan kualitas pelayanan restoran. Wu dan Liang (2009) mengungkapkan bahwa penyajian makanan dan minuman merupakan aspek penting dari kualitas makanan di restoran yang mewah dimana hal ini juga akan mempengaruhi emosi pelanggan restoran. Penelitian Lee et al. (2009), menyatakan bahwa ketika pembeli merasa bahwa restoran menawarkan berbagai makanan yang dinilai baik, mereka merasakan emosi positif seperti kegembiraan, kesenangan, kepuasan, kebanggaan yang berpengaruh pada proses pembelian ulang yang membentuk loyalty, sementara apabila makanan yang dijual tidak baik kualitasnya, maka pembeli akan merasa kecewa dan tidak puas yang berakibat pada tidak terjadinya proses pembelian ulang.

Restoran Domicile Kitchen \& Lounge memiliki komponen food quality. Berdasarkan penelitian ini dapat dibuktikan bahwa konsumen yang berkunjung ke Restoran Domicile Kitchen \& Lounge merasakan positive emotions. Pada uji hipotesis $\mathrm{H} 1 \mathrm{~b}$, food quality tidak memiliki pengaruh negatif pada negative emotions. Dengan demikian, H1b dari penelitian ini tidak terdukung. Hasil penelitian ini tidak sesuai dengan hasil penelitian Chen et al. (2015) maupun hasil penelitian Peng et al. (2016). Pada hipotesa H1b memiliki hasil yang berlawanan dengan hipotesa H1a. Hal ini menunjukkan situasi di Restoran Domicile Kitchen \& Lounge memang mendukung pada food quality yang berdampak pada positive emotions.

\subsection{Pengaruh Service Quality terhadap Emotions}

Hipotesis $\mathrm{H} 2 \mathrm{a}$, service quality memiliki pengaruh positif terhadap positive emotions. Dengan demikian H2a dari penelitian ini terdukung. Hasil ini sesuai dengan hasil penelitian yang dilakukan oleh Chen et al. (2015) dan hasil penelitian yang dilakukan oleh Peng et al. (2016). Pelayanan Restoran Domicile Kitchen \& 
Lounge merupakan hal yang sangat mempengaruhi pendapat konsumen mengenai restoran tersebut. Pelayanan restoran tidak hanya penting sebagai first impression pada konsumen namun juga mempengaruhi persepsi konsumen mengenai kualitas layanan restoran tersebut. Kualitas layanan Restoran Domicile Kitchen \& Lounge mencakup persepsi konsumen secara keseluruhan terhadap inferioritas maupun superioritas penyedia layanan.

Ribeiro \& Prayag (2018) berpendapat bahwa pelanggan yang merespon emosional positif terhadap karyawan yang berhubungan dengan kualitas pelayanan akan memiliki hubungan yang lebih kuat dan menjadi lebih berkomitmen dan loyal untuk melakukan pembelian kembali. Sementara, apabila pelanggan merespon emosional secara negatif terhadap kualitas pelayanan yang diberikan oleh karyawan, maka akan membentuk hubungan yang tidak berlangsung dalam jangka panjang. Sehingga, penelitian ini mengusulkan hipotesis bahwa persepsi konsumen terhadap kualitas suatu layanan akan mempengaruhi emosi positif mereka secara positif dan mempengaruhi emosi negatif mereka secara negatif pula. Pada uji hipotesis $\mathrm{H} 2 \mathrm{~b}$, service quality memiliki pengaruh negative terhadap negative emotions. Hasil uji hipotesa H2b sesuai dengan hasil penelitian yang dilakukan oleh Chen et al. (2015) dan Peng et al. (2016). Uji kedua hipotesa ini (H2a dan H2b) mendukung hasil penelitian Chen et al. (2015) dan Peng et al. (2016). Hal ini menunjukkan situasi di Restoran Domicile Kitchen \& Lounge diyakini memiliki service quality yang baik.

\subsection{Pengaruh Atmospherics terhadap Emotions}

Hipotesis $\mathrm{H} 3 \mathrm{a}$, atmospherics tidak memiliki pengaruh positif pada positive emotions. Dengan demikian, H3a dari penelitian ini tidak terdukung. Hasil penelitian ini tidak sesuai dengan hasil penelitian Chen et al. (2015), namun sesuai dengan hasil penelitian yang dilakukan oleh Peng et al. (2016). Hipotesis H3b, atmospherics tidak memiliki pengaruh negatif pada negative emotions. Dengan demikian, H3b dari penelitian ini tidak terdukung. Hasil penelitian ini tidak sesuai dengan hasil penelitian Peng et al. (2016), namun sesuai dengan hasil penelitian yang dilakukan oleh Chen et al. (2015). Menurut Essawy (2019) bahwa atmosfer suatu lingkungan memiliki dampak yang besar terhadap pengalaman dan perilaku konsumen. Dalam konteks restoran, Liu dan Jang (2009) menemukan bahwa atmospherics dapat mempengaruhi emosi positif dan negatif pelanggan.

Menurut Mowen dan Minor (2012) apabila atmospherics di restoran tersebut membuat pelanggan nyaman maka akan membentuk emosi positif pelanggan yang akan berdampak pada keputusan pelanggan untuk meningkatkan pembelian dan apabila atmospherics di restoran tersebut membuat pelanggan tidak nyaman maka akan membentuk emosi negatif pelanggan, sehingga pelanggan hanya membeli secukupnya yang kemudian tidak akan kembali lagi di tempat tersebut. Kondisi yang terjadi di Restoran Domicile Kitchen \& Lounge menunjukkan bahwa atmospherics resto tersebut diyakini baik dan nyaman, sehingga atmospherics ini tidak sepenuhnya mendukung pada positive emotions. Hal ini dikarenakan positive emotions pelanggan Restoran Domicile Kitchen \& Lounge didominasi pada food quality dan service quality. Pada uji H3b, kondisi atmospherics di Restoran Domicile Kitchen \& Lounge memang tidak menciptakan negative emotions pelanggan.

\subsection{Pengaruh Other Customers terhadap Emotions}

Hipotesis $\mathrm{H} 4 \mathrm{a}$, other customers memiliki pengaruh positif terhadap positive emotions. Dengan demikian $\mathrm{H} 4 \mathrm{a}$ dari penelitian ini terdukung. Hasil ini tidak sesuai dengan hasil penelitian yang dilakukan oleh Chen et al. (2015) maupun hasil penelitian yang dilakukan oleh Peng et al. (2016). Hipotesis H4b, other customers memiliki pengaruh negatif terhadap negative emotions. Dengan demikian $\mathrm{H} 4 \mathrm{~b}$ dari penelitian ini terdukung. Hasil ini sesuai dengan hasil penelitian yang dilakukan oleh Chen et al. (2015) dan hasil penelitian yang dilakukan oleh Peng et al. (2016). Pada 
studi Miao dan Mattila (2013) tentang restoran mewah menunjukkan bahwa seorang pelanggan akan berpengaruh terhadap pelanggan lain, bahkan terkadang bisa saling berinteraksi satu sama lain. Karena itu, dapat disimpulkan bahwa emosi seorang pelanggan dapat dipengaruhi oleh interaksi-interaksi ini. Interaksi-interaksi tersebut yang dapat membentuk emosi positif maupun emosi negatif pelanggan.

Menurut Brocato (2012) mengatakan bahwa seseorang akan lebih tertarik pada suatu hal jika ia mendapat dorongan yang lebih. Sehingga dalam hal ini apabila pelanggan saling berinteraksi berkumpul dalam kelompok untuk membicarakan suatu produk atau jasa yang memberikan image menurut mereka positif, mereka akan melakukan pembelian kembali pada produk atau jasa tersebut dan merekomendasikan produk atau jasa tersebut kepada pelanggan lain. Namun apabila selama proses interaksi pelanggan menceritakan bahwa produk atau jasa yang dijual dengan image negatif maka pelanggan lain yang ada dalam interaksi tersebut tidak akan tertarik untuk membeli produk atau jasa tersebut. Kondisi tersebut terjadi pula pada Restoran Domicile Kitchen \& Lounge. Interaksi antar pelanggan yang ada di Restoran Domicile Kitchen \& Lounge akan mempengaruhi positive dan negative emotions.

\subsection{Pengaruh Emotions terhadap Loyalty}

Uji hipotesis $\mathrm{H} 5 \mathrm{a}$, positive emotions memiliki pengaruh positif terhadap loyalty. Dengan demikian H5a dari penelitian ini terdukung. Hasil ini sesuai dengan hasil penelitian yang dilakukan oleh Chen et al. (2015) dan hasil penelitian yang dilakukan oleh Peng et al. (2016). Hipotesis H5b, negative emotions memiliki pengaruh negatif terhadap loyalty. Dengan demikian $\mathrm{H} 5 \mathrm{~b}$ dari penelitian ini terdukung. Hasil ini sesuai dengan hasil penelitian yang dilakukan oleh Chen et al. (2015) dan Peng et al. (2016). Menurut Oliver (1999), loyalitas dapat didefinisikan sebagai komitmen pelanggan untuk membeli ulang atau menjadi pelanggan suatu produk atau layanan secara konsisten di masa yang akan datang.

Jang dan Namkung (2009) dan Jeon dan Hyun (2012) mengatakan bahwa emosi positif atau kepuasan konsumen terhadap suatu produk dapat menyebabkan tingkat loyalitas yang lebih tinggi. Dengan kata lain, pelanggan dengan tingkat emosi positif yang tinggi lebih cenderung menjadi pelanggan tetap dan lebih cenderung untuk merekomendasikan suatu produk atau bisnis kepada teman dan keluarga. Mengenai pengaruh emosi negatif, Ou dan Verhoef (2017) mengatakan bahwa emosi negatif juga dapat mempengaruhi loyalitas pelanggan secara negatif. Dengan kata lain, pelanggan yang mengalami tingkat emosi negatif yang tinggi cenderung tidak merekomendasikan atau mengunjungi restoran yang sama di masa yang akan datang. Diketahui pelanggan Restoran Domicile Kitchen \& Lounge mayoritas merupakan pelanggan loyal. Adanya pelanggan loyal disebabkan karena ada perasaan senang yang merupakan bentuk positive emotions. Sebagaimana uji hipotesa yang sebelumnya telah diketahui faktor pendukung terwujudnya positive emotions.

\section{SIMPULAN}

Berdasarkan hasil penelitian tersebut, dapat disimpulkan bahwa ada 3 hipotesa yang terdukung antara lain service quality berpengaruh terhadap positive emotions dan negative emotions pada restoran Domicile Kitchen \& Lounge Surabaya, other customers berpengaruh terhadap positive emotions dan negative emotions pada restoran Domicile Kitchen \& Lounge Surabaya dan positive emotions dan negative emotions berpengaruh terhadap loyalty pada restoran Domicile Kitchen \& Lounge Surabaya. Pada pengujian variable atmospherics tidak memiliki pengaruh terhadap positive emotions dan negative emotions pada restoran Domicile Kitchen \& Lounge Surabaya. Pada uji mediasi menunjukkan hasil terdukung secara sebagian yaitu 
pada food quality tidak memiliki pengaruh terhadap negative emotions pada restoran Domicile Kitchen \& Lounge Surabaya, akan tetapi food quality memiliki pengaruh terhadap positive emotions pada restoran Domicile Kitchen \& Lounge Surabaya.

Dari hasil penelitian tersebut dapat diketahui implikasi penelitian bahwa service quality yang memiliki pengaruh terbesar terhadap positive dan negative emotions pada restoran Domicile Kitchen \& Lounge Surabaya. Oleh karena itu, restoran Domicile Kitchen \& Lounge Surabaya harus tetap menjaga kualitas layanannya dengan memberikan pelayanan yang profesional terhadap pelanggan. Hal ini dapat dicapai dengan memberikan feedback kepada pelanggan mengenai kualitas layanan yang ada, kemudian akan dievaluasi apa saja yang kurang dari layanan yang diberikan oleh restoran Domicile Kitchen \& Lounge Surabaya, layanan yang kurang tersebut kemudian akan diperbaiki dengan memberikan training yang lebih kepada karyawan restoran Domicile Kitchen \& Lounge Surabaya.

\section{REFERENSI}

Asshidieqi, F., \& Mudiantoro. (2012). Analisis Pengaruh Harga, Desain Produk dan Citra Merek Terhadap Keputusan Pembelian (Studi Kasus Pada Produk Crozz di Distro Ultra Store Semarang). Diponegoro Journal of Management. Semarang: Universitas Diponegoro.

Ayodya, W. (2007). Kursus Singkat Usaha Rumah Makan Laris Manis. Jakarta: PT Elex Media Komputindo.

Brocato, E.D., Voorhees, C.M. and Baker, J. (2012), Understanding the influence of cues from other customers in the service experience: A scale development and validation. Journal of Retailing,88(3), 384-398.

Chen. (2015). The Effect of Luxury Restaurant Environments on Diner's Emotions and Loyalty : Incorporating Diner Expectations Into a Extended MehrabianRussell Model. International Journal of Contemporary Hospitality Management, 27, 236-260.

Cozby. P \& Bates, S. (2020). Methods in Behavioral Research 14th Edition. McGraw Hill

https://www.jpnn.com/news/bisnis-kuliner-di-surabaya-tumbuh-pesat (diakses pada 6 April 2019)

https://www.selasar.com/jurnal/40190/Pangan-Fungsional-Tren-MakananMasa- Depan-Masyarakat-Indonesia (diakses pada 10 Maret 2019).

Jang, S. and Namkung, Y. (2009), Perceived quality, emotions, amd behavioural intentions: Application of an extended Mehrabian-Russell model to restaurants, Journal of Business Research, 62(4), 451-460.

Jeon, S.M. and Hyun, S.S. (2012). Examining the influence of casino attributes on baby boomers' satisfaction and loyalty in the casino industry, Current Issues in Tourism, 16(4), 343-368.

Lee, Y., Back, K. \& Kim, J. (2009). Family Restaurant Brand Personality and Its Impact on Customer's Emotion, Satisfaction, and Brand Loyalty. Journal of Hospitality \& Tourism Research, 33 (3), 305-328.

DOI: $10.1177 / 1096348009338511$

Li Miao., \& Mattila, A.S. (2013). The Impact Of Other Customers On Customer Experiences: A Psychological Distance Perspective. Journal of Hospitality \& Tourism Research, 37(1), 77-99. DOI: 10.1177/1096348011425498

Liu, Y., \& Jang, S(S). (2009), The effects of dining atmospherics: An extended Mehrabian-Russell model, International Journal of Hospitality Management, 28(4), 494-503. 
Essawy, M. (2019) The impacts of e-atmospherics on emotions and on the booking intentions of hotel rooms. Tourism and Hospitality Research 2019, 19(1), 65-73. DOI: $10.1177 / 1467358417692393$ journals.sagepub.com/home/thr

Mowen, John C \& Minor, Micheal. (2012). Perilaku Konsumen. Dialih bahasakan oleh Dwi Kartika Yahya. Jakarta : Erlangga.

Oliver, R.L. (1999), "Whence consumer loyalty?”, Journal of Marketing, 63, 33-44.

$\mathrm{Ou}, \mathrm{Y}-\mathrm{C}$ and Verhoef, PC (2017) The impact of positive and negative emotions on loyalty intentions and their interactions with customer equity drivers. Journal of Business Research, 80, 106-115.

DOI https://doi.org/10.1016/j.jbusres.2017.07.011

Peng. (2016) The Effects of Teppanyaki Restaurant Stimuli on Diners' Emotions and Loyalty, International Journal of Contemporary Hospitality Management, 60.

Ramanathan, R.YDI., \& Ramanathan, U. (2016). Moderating Roles of Customer Characteristics On The Link Between Service Factors Factors and Satisfaction In A Buffet Restaurant. Benchmarking : An International Journal, 23.

Ribeiro, M. A., \& Prayag, G. (2018). Perceived Quality and Service Experience: Mediating Effects of Positive and Negative Emotions. Journal of Hospitality Marketing \& Management. doi:10.1080/19368623.2018.1517071.

Wu, C.H-J., \& Liang, R-D. (2009), "Effect of experiential value on customer satisfaction with service encounters in luxury-hotel restaurants", International Journal of Hospitality Management, 28, 586-593. 
Halaman ini sengaja di kosongkan 